\title{
Taxation as a Stimulus for Economic Growth in Nigeria
}

\author{
Adigwe, Pretty Dennis (ANAA) Dr. Oyadonghan Kereotu James (ACA, ACTI, MNAA) \\ Department of Accounting, Faculty of Management Sciences, Niger Delta University, Wilberforce Island. PMB \\ 071, Yenagoa, Bayelsa State, Nigeria
}

\begin{abstract}
This study examined taxation as a stimulus for economic growth and development in Nigeria. The problem of over dependence in oil income has marred the nation sustainable development, several scholars and agencies are clamouring for revenue diversification for the economy. Since technological growth is a long way to achieve in the economy, tax could be considered as an immediate option to the problem. Tax is a major source of government revenue all over the world and Nigeria is not an exception. The tax system is an opportunity for the government to assemble extra revenue needed in discharging economic development and creating a conducive business environment for its citizens. This study used yearly time series data from the Central Bank of Nigeria (CBN) Statistical Bulletin for the period of 2009 to 2018 and a linear model of Corporate Income Tax (CIT), Value Added Tax (VAT) and Economic Growth (GDP) was appraised using the Ordinary Least Square (OLS) technique. The results gotten from this study revealed that the hypothesized connection among corporate income tax, value added tax and economic growth really exist in Nigeria. Thus the result gives the confirmation that taxation is indeed a stimulus for economic growth and development in Nigeria. This conclusion has revealed the need for government to institute extra methods or processes that will make taxpayers not to avoid and evade tax so that revenue can be properly generated, and income effectively redistributed and allocated in the economy.
\end{abstract}

Keywords: Taxation, Economic growth, Development, Gross Domestic Product

DOI: $10.7176 /$ RJFA/11-2-07

Publication date: January $31^{\text {st }} 2020$

\section{Introduction}

The growth and development of a country is influenced by the amount of income set aside for the provision of infrastructure. One major means of generating income for the provision of key infrastructure is through a wellstructured tax system. As a result, the significance of taxation in the activities of any government cannot be ignored because it is one of the major sources of government income used for promoting economic growth and development in a country. Although, most governments have not been able to efficiently and effectively exploit this great opportunity of revenue generation. This can be credited to a number of reasons including the system of taxation; tax legislation; tax administration and policy issues; over reliance on other sources of revenue (such as oil); corrupt practices in the system (especially as it relates to the system of tax collection) and behaviour of citizens towards tax payment and method of tax payment (Akintoye and Tashie, 2013).

One of the commonly discussed problems in Economics is how tax relates to economic growth and development. Hence, Azubike (2009) claimed that tax is a major player in every society of the world as regards government income. The tax system is an opportunity for government to gather additional revenue needed in settling its demanding responsibilities. Taxation offers itself as one of the most effective means of stimulating a nation's internal resources and it provides an environment favourable to the promotion of economic growth. Anyanwu (1997) defined taxation as the compulsory transfer or payment of income (either on goods and services) from private individuals, institutions or groups to the government. Appah (2004); Appah and Oyadonghan (2011) also defined tax as a compulsory levy imposed on a subject or upon his property by the government to offer security, social amenities and create conditions for the economic wellbeing of the society.

The main purpose of taxation is to raise revenue to meet government expenditure and to reallocate wealth to various areas for the management of the economy (Bhartia, 2009). Moreover, Nzotta (2007) claimed that tax is one of the main sources of revenue to the federation account, which is shared amongst the federal, state and local governments in Nigeria. Emmanuel (2010) opined that developed and developing economies around the world have experimented and proven that no nation can truly develop without developing its tax system. Hence, many countries have introduced tax reforms and reorganization with a sight of developing a tax system that exploits government revenue without creating disincentives for investment (Kizito, 2014).

\section{Statement of the problem}

The revenue gotten from taxes has been very low over the years and the impact on infrastructural development is relatively low, hence the effect on the society is not being felt the way it ought to. The core problems that will be addressed in this study includes: Insufficient tax staff, dishonest activities of tax administrators and lack of understanding of the significance of tax revenue by tax payers. The following research questions are formulated to guide the study: 
(i) What degree has taxation through Corporate Income Tax and Value Added Tax contributed to economic growth and development in Nigeria?

(ii) In what ways can Nigeria modernised her tax system in order to boost revenue generation through Taxation?

\section{Objective of the study}

In Nigeria, government has focused almost totally on oil revenue without paying attention to the income that could be realised from taxation. This has made the tax system to suffer because it has not been well monitored and supervised. Based on this lapse, this study tends to explore the importance of tax and how it can stimulate a country's growth and development by using Corporate Income Tax (CIT) and Value Added Tax (VAT) to measure Taxation and Gross Domestic Product (GDP) to measure economic growth. In particular, this paper contends that taxation stimulates economic growth. The primary objective of this study was to investigate the relationship between tax and economic growth and development in Nigeria.

\section{Hypotheses of the Study}

The hypothesis for this study are:

H01: Corporate Income Tax (CIT) has no significant impact on Economic growth in Nigeria.

H02: Value Added Tax (VAT) has no significant impact on economic growth in Nigeria.

\section{Scope of the Study}

The content of this research covers Tax proceeds and generation of revenue from CIT and VAT for a period of 10 years and Gross domestic product for the same period covering 2009 to2018. The geographical scope is Nigeria and the unit of analysis is secondary data from Central Bank of Nigeria Bulletin.

\section{Literature review \\ Conceptual Review}

Tax is an unavoidable charge that is been paid to the government of a nation in order for the government to provide basic amenities for the individuals of that nation such as security, roads, pipe borne water etc (Appah and Oyadonghan, 2011). From the above, one could say that taxes are enforced on every individual of a country, who is earning income either directly or indirectly from the production of goods and services. Tax is a huge source of income to the government as it helps the government to keep its obligation of ensuring the well-being of citizens. Further, the economic and socio-political expansion of any nation could be affected basically by the amount of income generated through taxation for the provision of infrastructure that can enhance economic growth (Adudu and Simon 2015).

Adams (2001) asserts that taxation is one of the greatest source of revenue for present governments, usually accounting for ninety percent or more of their income. Taxation as perceived by Aguolu (2004), is an unavoidable charge by the government through its agencies on the income, capital and consumption of its subjects. These levies are made on personal income, such as business profits, royalties, discounts, interest, salaries and dividends. It is also imposed on company's profits petroleum profits, capital gains and capital transfer. However, Ojo (2008) strains that taxation is a notion and the science of imposing tax on citizens. According to him, tax is an obligatory charge which is mandatory to be paid by every citizen. It is commonly considered as a public responsibility. The imposition of taxation is anticipated to produce income which should be utilized in the establishment of facilities, both social and security, which can create situations for the economic well-being and safety of society.

\section{Economic growth and development}

The major aim of economic development is to create an environment that makes provision for local communities and regions to grow new ways of production of goods in such measures that may lead to exportation to other countries. Making financial resources available for exportation can lead to more investment in infrastructure for the benefit and development of living conditions of people when it comes to education, health, transportation networks, water supply, sewage and sanitation (Salmon Valley Business Innovation Centre, 2014).

Economic development varies from economic growth, economic growth precisely means a rise in the value of goods and services produced by a country over a period and Economists measure it with the rise in a country's Gross Domestic Product (GDP). Thus, it is possible to have economic growth without economic development (Hadjimichael, Kemenyy and Lanahan., 2014). This means, there could be an increase in GDP without any increase in the standard of living of people in a state or country. Environmental conditions that would improve economic growth must be made through investment as this can bring about economic development.

The economic growth and development of any country depends on the amount of revenue generated for the establishment of infrastructure and basic amenities in that country. However, one key means of generating the amount of revenue for the provision of needed infrastructure and basic amenities is through a well-structured tax system (Ogbonna and Appah, 2012). This is possible when the basic things of life including law and order, security 
and education are provided by government.

Soyode and Kajola (2006) have enumerated the responsibilities or objectives of government when there is an income generated from taxation. These objectives and responsibilities include:

(a) Revenue Generation: The primary objective of a modern tax system is to generate revenue to help government finance public sector expenditures.

(b) Provision of basic amenities: Another key objective of tax is the provision of social, economic and good governance through the provision of basic amenities. For example, good health centres and education. The provision of these amenities should not be left completely to private organisations even though private participation should be encouraged.

(c)Provision of Public Goods: The revenue generated from tax in a country can be used to provide goods and services that are generally consumed for example:

(i) External security through defence against external aggression by Army,

Navy and Air Forces,

(ii) Internal security through maintenance of law and order by police and other

security agencies. and

(iii) The Provision of street lights and roads.

(d) Redistribution of Income and Wealth: Tax system is a means of confirming the redistribution of income and wealth in order to reduce poverty and encourage social welfare. For example, a tax system is one of the means of attaining economic regulation for promotion of economic stability and sustainable growth through fiscal policy. Government also has responsibility for fighting inflation, unemployment and creating a sound infrastructure for business.

(e) Harmonization of Economic Objectives: One of the objectives of taxation is the synchronisation of different trade and economic objectives of different countries. For example, tax system can be used to attain the philosophy of the single market in ECOWAS or Africa so as to enable free movement of goods and services and people between member states.

\section{Tax Structures in Nigeria}

A good tax system plays a vital role in the process of economic growth and development of any country including Nigeria (Appah, 2010). Taxes can be direct or indirect and may be enforced on individuals, entities, on assets and on transactions.

On Individuals: The following are taxes imposed on individual's income.

1. Personal Income Tax - This is tax levied on the income of all Nigerian citizens or residents who derive income in Nigeria.

2. Development Levy - This is a flat charge levied on every taxable individual within a State.

On Companies (Corporations)

1. Companies Income Tax - This type of tax is levied on the profits of all corporate entities who are registered in Nigeria, other than those engaged in petroleum operations.

2. Petroleum Profits Tax -This type of tax is levied on the profits of all corporate entities who are engaged in oil and gas operations in Nigeria;

3. Education Tax - This type of tax is levied on all corporate entities registered in Nigeria.

4. Technology Levy - This is a type of tax imposed on telecommunication organisations, internet service providers, banks, pension managers, insurance companies and other financial institutions.

\section{On Transactions}

1. Value Added Tax - This tax is enforced on the net sales value of non-exempted, qualifying goods and services in Nigeria.

2. Capital Gains Tax - This tax is levied on capital gains derived from the sale or disposal of chargeable assets.

3. Stamp Duty - This is levied on instruments executed by individuals and corporate entities in Nigeria.

4. Excise Duty - This is imposed on the manufacture of goods within the Government territory collected by the Nigerian Customs Service.

5. Import Duty - This is imposed on goods imported into the Government territory collected by the Nigeria Customs Service

6. Export Duty - This type of tax is levied on goods exported outside the Government territory collected by the Nigeria Customs Service.

\section{Theoretical Review}

There are different theories that have been used to explain what taxation is, Bhartia, (2009) in Ogbonna and Appah (2012), has identified some of the theories of taxation to include: Socio-political theory, benefit received theory, the expediency theory, faculty theory etc. according to Bhartia (2009), The socio-political theory of taxation explains that the aim of collecting taxes from individuals should be to help reduce the sufferings in the society, by 
considering their well-being in providing for their basic amenities and should not be for individual's private use. The benefit received theory asserts that there is an exchange relationship between the tax payer and government. The government offers basic amenities like security, electricity, pipe born water etc to the tax payer and he contributes a certain percentage of money to the government according to his level of income. The expediency theory affirms that every tax proposed should be practically proven and the faculty theory states that people should be taxed according to their ability to pay. That is, individuals should pay tax according the amount of income they earn.

In order to understand further the impact or effects of tax on economic growth, there is a need to look at the two economic schools of thought. They are the traditional economic school and the modern school. In the traditional economic school, Robert Barro summarized his view in Slemrod (2003) works in Adudu and Simon (2015) that when other determinants of growth are held constant, low tax rates and low government spending are associated with higher levels of growth. This indicates that the higher the marginal tax rate, the greater the chances of higher income tax payers averting extra time from productive processes to leisure activities. The modern school of thought explained that higher marginal tax rates are capable of bringing about better economic development in the long-run. This is possible because the government would be acquiring higher income which when capitalised in a nation's education and development of infrastructure could boost the economy (Adudu and Simon 2015).

\section{Empirical evidence of tax as a stimulus to economic growth and development}

A lot of studies have been done by different authors on how taxation can affect the economic growth of a country. For instance, Ogbonna and Appah (2012) studied the impact of Tax Reforms and Economic Growth of Nigeria and found that tax reforms are positively and significantly related to economic growth and that tax reforms can improve economic growth. The study concluded that tax reforms can expand government's process of generating revenue. In addition, Adudu and Simon (2015) studied the Impact of Tax Policy on Economic Growth in Nigeria and found that efficient tax reforms are necessary conditions for the development of sustainable economic growth.

Chiumia and Simwaka, (2012) examines the effect of taxation in sub-Saharan Africa. They found that taxes charged on personal and corporate income decreases economic growth. From the above, one may deduce that the tax structure is largely irrelevant in less developed economies, but an effective tax structure brings benefits for both the taxpayers and the government.

Olusanya, Peter and Oyebo (2012) studied taxation as a fiscal policy tool for income reallocation among Lagos state civil servants. They used the spearman's rank correlation coefficient to analyse the data they collected. The study revealed that there is a positive relationship between tax as a fiscal policy tool and income reallocation.

Engenand and Skinner (1996) who studied the relationship between taxation and economic growth of the United State, establish that there is a modest effect on the direction of 0.2 to 0.3 percentage point changes in growth rates in answer to major tax reforms. Their findings propose that such slight influence can cumulatively have large impact on the standards of living of citizens.

Adereti, Adesina and Sanni (2011) studied the effect of value added tax and economic growth in Nigeria, he found out that there is no connection existing between GDP and VAT revenue, but there is a positive significant relationship between VAT and GDP revenue. Tosun and Abizadeh (2005) studied economic growth and tax charges in OECD countries from 1980 to 1999. Their study disclosed that economic growth measured by GDP per capital has major influence on tax combined with gross domestic product (GDP) per capita. The study documented a drop in shares of employee's payroll but a positive growth from personal and property taxes and goods and services.

Saez, (2004) study of direct and indirect tax mechanisms for redistribution: short-run versus long-run, he found that in a long-run situation individuals reply to tax motivations through the job-related boundary, which is in discrepancy to a short-run situation where individuals are caught into their jobs and can only regulate labour source on the job. Worlu and Emeka (2012) studied tax revenue and economic development in Nigeria by using the three stage least square estimation technique, they found that tax revenue is capable of boosting economic growth through infrastructural development, the study also highlighted the channels through which tax revenue effects on economic growth in Nigeria and also that tax revenue has no reliant on the effect of growth through infrastructural development and foreign direct investment but just allowing the infrastructural development and foreign direct investment to positively respond to rise in output.

Nwakanm aand Nnamdi, (2013) examined taxation and national development with the least square approach and specification on the lin-log model of human development table. Their results disclosed that Petroleum Profit Tax, Excise Tax and Company Income Tax reveal a positive relationship with the level of national development, and a negative relationship between human development index and corporate tax. Dackehag and Hansson (2012) in their study of how legal tax rates on corporate and personal income affects economic growth using panel data from 1975 to 2010 for 25 rich OECD countries establish that there is a negative impact on economic growth from both taxation of corporate and personal income. Their study also exposed a stronger economic growth in correlation with corporate income tax. 
Ferede and Dahlby, (2012) examined the effect of the Canadian provincial governments' tax rates on economic growth using panel data covering the period from 1977 to 2006 ; the study found that advanced provincial statutory corporate income tax rate is associated with lower private investment and slower economic growth. Their experimental estimation suggested that a 1 percent point cut in the corporate tax rate is related to a $0.1-0.2$ percentage point increase in the annual growth rate. The outcome of their research work shows that sales tax improves a country's investment and growth when converted from a trade sales tax to a synchronised sales tax with central value added.

Padovano and Galli, (2001) created tax measures and included a dummy slope to allow changes in tax rates over time in their study on the relationship between marginal tax rates and economic growth. There work revealed that tax charges have negative and statistical significance on growth. In the same manner their study in 2002 ultimately confirmed a negative correlation between marginal tax rates and economic growth, and average tax rates have significant effect on economic growth and development.

\section{Methodology}

This study used a time series ex-posfacto design with an appraisal of a linear regression model and employed secondary data sourced from the Central Bank of Nigeria (CBN) Statistical Bulletin from the period of 2009 to 2018. This study used Ordinary Least Square (OLS) technique in analysing the data and measuring the parameters of the model by means of the Statistical Package for Social Sciences (SPSS) version 20. The linear model for this study was chosen because others in this area of study also used it; for example, Ferede and Dahlby, (2012); Chiumia and Simwaka, (2012) and Dackehag and Hansson (2012). In line with these studies mentioned above, Grose Domestic Product (GDP) was used as an instrument to measure economic growth as the dependent variable and Value Added Tax (VAT) and Corporate Income Tax (CIT) are used as proxies for Taxation as the independent or explanatory variables in the model. The model for this study is:

$\mathrm{GDP}=\mathrm{F}(\mathrm{CIT}, \mathrm{VAT}) \boldsymbol{e q} . \mathbf{1}$

GDPit $=\mathrm{a} 0+\mathrm{b}_{1}$ CITit $+\mathrm{b}_{2}$ VATit + et eq.2

Where:

GDP $=$ Gross Domestic Product, CIT $=$ Corporate Income Tax, VAT = Value Added Tax

$\mathrm{a} 0, \mathrm{~b}_{1}, \mathrm{~b}_{2}=$ Regression Coefficient

$\varepsilon \mathrm{t}=$ Error Term and it $=$ Time dimension

\section{Results and Discussion}

The results of the Ordinary Least Square (OLS) regressions are summarised and presented in the table below:

Table I: OLS Results

\begin{tabular}{l|l|l|l|l|l|l}
\hline \multicolumn{2}{l|}{ Variables } & \multicolumn{5}{l}{ Key Statistical Indicators } \\
\hline GDP & $\begin{array}{l}\text { Pearson } \\
\text { Correlation }\end{array}$ & f-statistics & t-statistics & $\begin{array}{l}\mathrm{R}^{2} \\
\text { unadjusted }\end{array}$ & $\begin{array}{l}\text { Adjusted } \\
\mathrm{R}^{2}\end{array}$ & $\begin{array}{l}\text { Durbin } \\
\text { Watson }\end{array}$ \\
\hline CIT & .753 & 43.645 & 7.445 & .921 & .832 & .740 \\
\hline VAT & .583 & 9.6450 & 4.211 & .723 & .743 & .122 \\
\hline Constant & 1.00 & & -2.7577 & & & \\
\hline
\end{tabular}

Dependent variable: GDP

Independent Variable: CIT, VAT

From the results evaluated in the table above, the independent variables (CIT and VAT) were correlated perfectly and there is a multi-collinearity in the result with the dependent variable (GDP) constant with 1. Corporate Income Tax (CIT) at .753 and Value Added Tax (VAT) at .583. In appraising the goodness of fit in the model, the unadjusted R-Squared of .921 means that 92.1 percent of change in GDP is explained by the CIT and .723 of GDP means that 72.3 percent of GDP has been explained by the VAT. The values for CIT and VAT are exciting and high since the unexplained variation is just 7.7percent $(1-.921)$ and 14.5percent $(1-.723)$ respectively. The adjusted $\mathrm{R}^{2}$ of .83 .2 , means 83.2 percent is the exact value of CIT that explained the GDP which is remarkable and high since the unexplained variation is just 7.4 percent $(1-.936)$. Also, with the adjusted $\mathrm{R}^{2}$ of .832 , it means 83.2 percent is the right value of VAT that explained the GDP which is notable and high since the unexplained variation is just 17 percent $(1-.743)$.

In computing the Analysis of Variance (ANOVA) in the regression model, the f-statistics test computed for CIT showed a figure of 43.645 and VAT displayed a figure of 9.6450 at 5\% level of significance. Therefore, with all the above-mentioned explanations and analysis, it suggests that CIT and VAT have significant impact on economic growth in Nigeria, this answers the hypothesis H01. The Durbin Watson (DW) test with values .740 and .122 for CIT and VAT respectively shows that there is no reality of first order serial correlation in the model. Thus, the empirical results are suggestive; signifying that the hypothesized impact of Corporate Income Tax (CIT), Value Added Tax (VAT) on Economic Growth (GDP) indeed exist in the Nigerian context. The findings of this 
study implies that taxation is a stimulus for economic growth in Nigeria.

\section{Conclusion}

This study has discovered that there is a relationship between some parameters of taxation (Value Added Tax and Corporate Income Tax and Economic Growth (using the Gross Domestic Product as a measure) using annual time series data spanning 2009 through 2018 in a combining linear model. By concentrating on a possible measure of taxation that has not been studied previously in other African countries, this paper contributes to literature in Nigeria that tries to understand whether taxation is a stimulus for economic growth or not. The empirical results gave an evidence that taxation is a stimulus for economic growth and development in Nigeria.

\section{Recommendation}

The following are some of the recommendations made as a result of this study:

a) There is a need for all state governments to evidently state the basic objectives of its tax system. This will help to give the tax managers a sense of direction and make the tax payer see evidently the reasons he/she should pay his/her tax as at when due.

b) The tax collection mechanism used by tax officials should be free from corruption and misappropriation. If this is not done the revenue collected may not reach the desired point.

c) Regulatory authorities charged with the responsibility of collecting tax should be strengthened further to ensure compliance by tax payers. Again, the tax revenues should be properly accounted for and utilized so that economic growth can be seen, especially in providing basic amenities as well as infrastructure in Nigeria.

\section{References}

Adams, C. (2001) For Good and Evil; The impact of Taxes on the Course of Civilization, U. S. A; Madison Publishers. 45-50.

Adereti, S.A., J.A. Adesina and M.R. Sanni, (2011). Value added tax and economic /growth of Nigeria. European Journal of Humanities and Social Sciences, 10(1), 555-571.

Adudu, S., A. and Simon, O., M (2015). The Impact of Tax Policy on Economic Growth in Nigeria, Journal of Economics and Sustainable Development, 6(8), 124-129.

Aguolu, O. (2004) Taxation and Tax Management in Nigeria, 3rd Edition, Enugu; Meridan Associates. 33-51.

Akintoye, I. R., and Tashie, G., A. (2013). 'The Effect of Tax Compliance on Economic Growth and Development in Nigeria, West-Africa'. British Journal of Arts and Social Sciences, 11(2), 222-230.

Anyanwu, J.C. (1997). 'Nigerian Public Finance’. Onitsha, Joanne Educational Publishers, 5- 10.

Appah, E. (2004). 'Principles and Practice of Nigerian Taxation'. Port Harcourt, Ezevin Mint Printers and Publishers, 20-30.

Appah, E. (2010), "The Problems of Tax Planning and Administration in Nigeria: The Federal and State Governments Experience", International Journal of Labour and Organisational Psychology, 4(1-2), 1-14.

Appah, E. and Oyadonghan, J., K. (2011). 'The challenges of tax mobilization and management in the Nigerian economy’. Journal of Business Administration, 6(2), 128136.

Azubike, J.U.B. (2009). 'Challenges of tax authorities, tax payers in the management of tax reform processes'. Niger. Account., 42(2), 36-42.

Bhartia, H.L (2009). Public Finance. New Delhi: Vikas Publishing House PVT Limited.

Chiumia, A. and Simwaka, K. (2012). Tax Policy Development, Donor Inflows and Economic Growth in Malawi. Journal of Economics and International Finance, 4(7), 159-172.

Dackehag, M. and Hansson, A. (2012). Taxation of Income and Economic Growth: An Empirical Analysis of 25 Rich OECD Countries. OECD Department Working Paper 20, 126.

Emmanuel, M. (2010). 'Nigerian Tax System: Entrenching New National Tax Policy'. Nigerian Tribune.

Ferede, E. and Dahlby, B. (2012). The Impact of Tax cuts on Economic Growth: Evidence from the Canadian Province. National Tax Journal, 63(3), 563-594.

Hadjimichael, F.M., T. Kemenyy and L. Lanahan, (2014). Economic development: A definition and model for investment. Available from http://www.edu.gov/tool [Accessed 28th September 2015].

Kizito, E. U. (2014). 'The Nexus between Tax Structure and Economic Growth in Nigeria: A Prognosis'. Journal of Economic and Social Studies, 4(1), 113-135.

Nwakanma, P.C. and Nnamdi, K.C. (2013). Taxation and National Development. Research Journal of Finance and Accounting, 4(19), 176-180.

Ogbonna, G.N. and Appah, E. (2012). 'Impact of Tax Reforms and Economic Growth in Nigeria: A Time Series Analysis. Journal of Social Science, 4(1), 62-68.

Olusanya, S.O., Peter, M. and Oyebo, A.F. (2012). Taxation as a Fiscal Policy Instrument for Income Redistribution among Lagos State Civil Servants. IOSR Journal of Humanities and Social Sciences, 5(10), 
60-70.

Padovano, F. and Galli, E. (2001). Tax Rate and Economic Growth in the OECD Countries (1950-1990). Economic Inquiry, 1(39), 44-57.

Saez, E. (2004). Direct or Indirect Tax Instruments for Redistribution: Short-run Versus Long-run. Journal of Public Economics, 88(1), 503-518.

Salmon Valley Business Innovation Centre, (2014). What is economic development? Available from www.subic.com/node/2.

Soyode, L. and Kajola, S.O (2006) Taxation Principals and Practice inNigeria, Ibadan, Nigeria; Solicon Publishers. Tosun, M.S. and Abizadeh, S. (2005). Economic Growth and Tax Components: An Analysis of Tax Change in OECD. Appl. Econ., 37(2), 251-263.

Worlu, C. N and Emeka, N. (2012). Tax Revenue and Economic in Nigeria: A Macroeconomic Approach.Academic Journal of Interdisciplinary Studies, 1(2), 211-223. 